\title{
Productive achievements in backyard poultry projects funded by the strategic program for food security at Tepecoacuilco, Guerrero, Mexico
}

\author{
Reza-Solís, Irad Jared ${ }^{1}$; León-Merino, Aurelio ${ }^{1^{*}}$; Valtierra-Pacheco, Esteban ${ }^{1}$; Hernández-Juárez, Martín ${ }^{1}$; \\ Santoyo-Cortes, Vinicio Horacio ${ }^{2}$ \\ ${ }^{1}$ Colegio de Postgraduados, Campus Montecillo. Estudios del Desarrollo Rural. Montecillo, Texcoco, Estado \\ de México. C. P. 56230. \\ ${ }^{2}$ Universidad Autónoma Chapingo, Centro de Investigaciones Económicas, Sociales y Tecnológicas de la \\ Agroindustria y la Agricultura Mundial (CIESTAAM). Chapingo, Texcoco, Estado de México. C. P. 56230. \\ *Corresponding author: laurelio@colpos.mx
}

Citation: Reza-Solís, Irad J., León-Merino, Aurelio, Valtierra-Pacheco, Esteban, Hernández-Juárez, Martín, \& SantoyoCortes, Vinicio H. (2021). Productive achievements in backyard poultry projects funded by the strategic program for food security at Tepecoacuilco, Guerrero, Mexico. Agro Productividad, 14(\#). https://doi.org/10.32854/agrop. v14i6.1885

Editor in Chief: Dr. Jorge Cadena Iñiguez

Estimated publication date: July 2021

This work is licensed under a Creative Commons Attribution-NonCommercial 4.0 International license

\begin{abstract}
Objective: To identify the socioeconomic factors in Tepecoacuilco, Guerrero that favored food production and family income that improves their food security via backyard poultry projects.

Methodology: 31 families with backyard poultry projects for chicken meat and egg production were surveyed and their information complemented with two participatory workshops.

Results: The average backyard area per family was $48.27 \mathrm{~m}^{2}$, of which $25.3 \mathrm{~m}^{2}$ were destined to the projects supported by the program. Only $16.1 \%$ of the assessed projects are in operation and families with active projects improved their diet by increasing their consumption of eggs and healthy meats. Regarding egg production, an annual average of $187.2 \mathrm{~kg}$ was obtained in operating projects.

Limitations: Local violence conditions in the study area limited interviewing all beneficiaries selected in the sample.

Conclusions: Beneficiaries improved their family diets with the financed projects; however, the results indicate that family needs are still not fully fulfilled, because the beneficiaries continue to buy eggs essential for their diets. The projects achieved little or no contribution to their household income.
\end{abstract}

Keywords: families, production, food security, backyards.

\section{INTRODUCTION}

The backyard is considered an agrosystem in rural households, where families produce food of animal and vegetable origin, medicinal and ornamental crops, fruits and shade trees. Raising minor species of domestic animals in backyards is a survival strategy of poor rural families that, by selling these, allow them to have cash income (Olvera-Hernández, 2017) to cover emergency or unexpected expenses. Among the commonly kept minor species by rural households are poultry, with Creole hens (Gallus gallus L.) and "guajolotes" (Meleagris gallopavo L.) standing out (Vargas-López, 2018). The Mexican government has promoted the Strategic Program for Food Security (PESA), where the developed projects included a backyard component to strengthen poor families. In 2007, the first PESA allocation (636.2 million Mexican pesos) was included in the Federal Expenditure Budget Decree (DPEF), year after year its budget amount increased, and it was only in 2016 and 2017 when it decreased (Torres-Oregón \& Rendón-Rojas, 2017) (Figure 1).

The PESA operated in Mexico to benefit more than a quarter of a million people considered among the poorest in rural areas (Torres-Oregón \& Rondón-Rojas, 2017) (Table 1). 


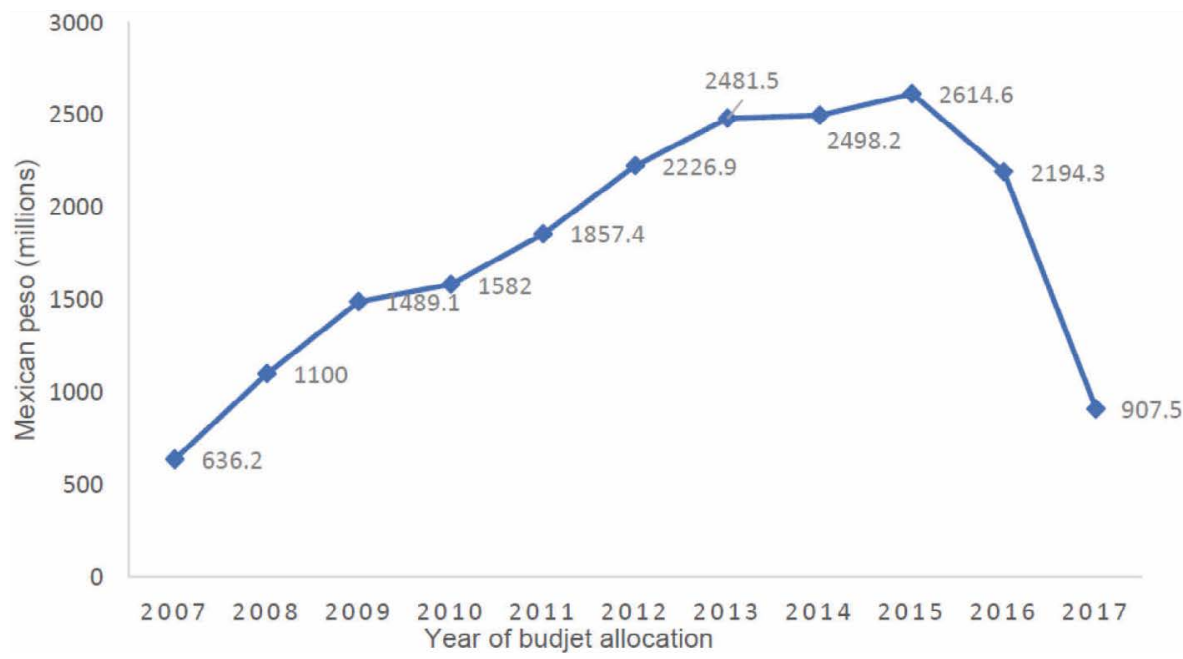

Figure 1. Budget of the Strategic Food Security Program (2007-2017). Source: Torres-Oregón \& Rendón-Rojas (2017)

Table 1. Coverage of the 2017 Strategic Food Security Program.

\begin{tabular}{|c|c|c|c|}
\hline State & Municipalities & Communities & Families \\
\hline Chihuahua & 17 & 261 & 2,924 \\
\hline Durango & 13 & 274 & 8,203 \\
\hline Zacatecas & 43 & 304 & 10,747 \\
\hline Nayarit & 11 & 142 & 5,103 \\
\hline San Luis Potosí & 24 & 488 & 17,163 \\
\hline Tamaulipas & 5 & 50 & 1,813 \\
\hline Jalisco & 5 & 48 & 1,270 \\
\hline Guanajuato & 3 & 77 & 1,266 \\
\hline Querétaro & 21 & 231 & 1,917 \\
\hline Hidalgo & 62 & 431 & 13,837 \\
\hline Colima & 10 & 50 & 949 \\
\hline Michoacán & 21 & 408 & 11,512 \\
\hline Estado de México & 15 & 240 & 4,996 \\
\hline Tlaxcala & 36 & 106 & 3,774 \\
\hline Puebla & 70 & 626 & 27,241 \\
\hline Veracruz & 2 & 0 & 0 \\
\hline Morelos & 23 & 115 & 7,944 \\
\hline Guerrero & 109 & 1,310 & 61,615 \\
\hline Oaxaca & 310 & 1,050 & 37,312 \\
\hline Chiapas & 82 & 953 & 48,281 \\
\hline Tabasco & 3 & 75 & 1,836 \\
\hline Campeche & 8 & 122 & 5,817 \\
\hline Yucatán & 12 & 45 & 953 \\
\hline Quintana Roo & 5 & 62 & 1,844 \\
\hline Total & 910 & 7,468 & 264,480 \\
\hline
\end{tabular}

Source: Torres-Oregón \& Rendón-Rojas (2017). 
In the state of Guerrero, the projects that predominated with the operation of the PESA were backyard projects, mainly the production of laying hens. The objective of this study was to identify the socioeconomic factors that favored improvements in the backyard production of families participating in the PESA, thus contributing to their food security.

\section{MATERIALS AND METHODS}

An ad hoc questionnaire was designed to record information from 31 interviews, conducted in August 2019, to the heads of households in the communities of Tierra Colorada, Lázaro Cárdenas, Acayahualco, Maxela and Xalitla, Municipality of Tepecoacuilco, state of Guerrero, which were listed as beneficiaries of the PESA backyard projects (Figures 2 and 3).

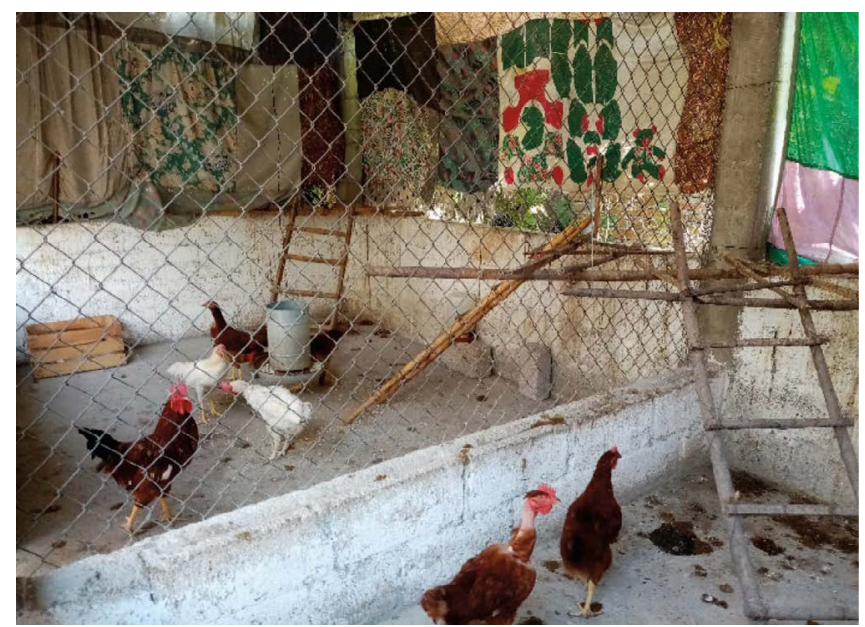

Figure 2. Operating bird gallery from the Strategic Food Security Program at Lázaro Cárdenas, Guerrero, Mexico.

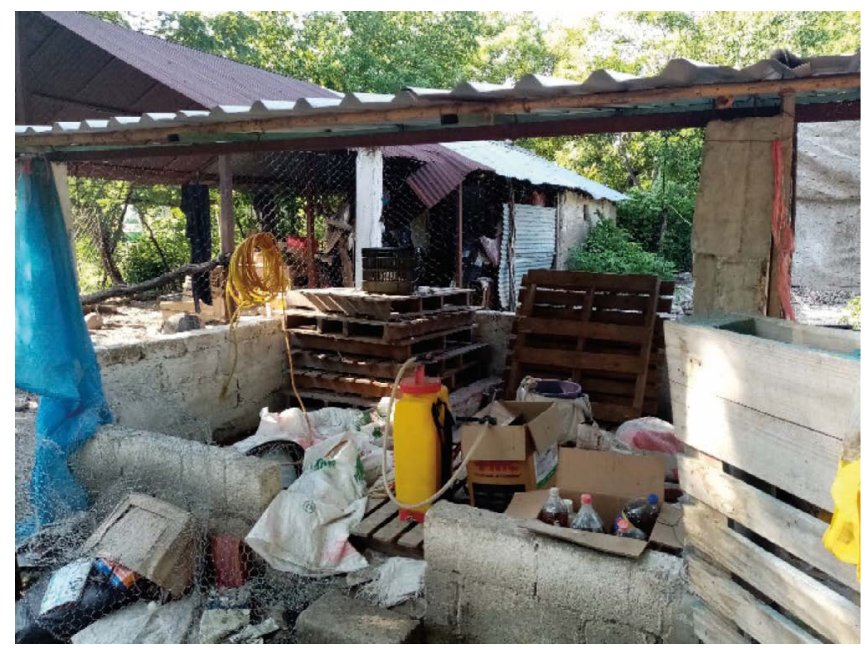

Figure 3. Non-operating bird gallery from the Strategic Food Safety Program at Tierra Colorada, Guerrero, Mexico. 
The sample size was determined by criterion (arbitrary) considering the social and economic situations of the region, so it was not a probability sampling. The selection consisted of interviewees enlisted as beneficiaries who had been participating in the program for at least three years to assess the impact of PESA support. The surveyed data was complemented with other information obtained from two participatory workshops.

An exploratory visit to the region was conducted in November 2018 with the support of the technical staff of the Rural Development Agency following up on the projects in the studied communities. The surveys were applied, and the participatory workshops were held during August 2019.

Tepecoacuilco municipality is located in the northern area of the state of Guerrero. It has a territorial extension of $984 \mathrm{~km}^{2}$, representing $1.54 \%$ of the total state area. It is located between $17^{\circ} 54^{\prime}$ and $18^{\circ} 22^{\prime}$ north latitude and $99^{\circ} 41^{\prime}$ west longitude (INEGI, 2010). The 2010 Population and Housing census reported a total population of 30,470 inhabitants in the municipality, of which 14,612 (47.96\%) were men and 15,858 (52.04\%) women (INEGI, 2010). The municipality's main economic activity is agriculture followed by livestock activities. With data from the recent 2015 poverty assessment conducted by the Consejo Nacional de Evaluación de la Política de Desarrollo Social (National Council for the Evaluation of Social Development Policy, CONEVAL, 2015), in the municipality of Tepecoacuilco, 26,108 individuals were in poverty, from which 20,186 (77.32\%) lived in moderate and 5,922 (22.68\%) in extreme poverty.

\section{RESULTS AND DISCUSSION}

The surveyed beneficiaries of the program were on average 49.4 years old and had 6 years of schooling (sixth grade of elementary school). In the state of Guerrero as age increases, the illiteracy rate also increases, being higher among women (INEGI, 2015), thereby indicating that the female population in poverty was denied the right to education. This coincides with the results found in this research. The highest age percentage of the female respondents was found in the range of 55 and 64 years (32.40\%), who had a schooling level of the third year of elementary school. The interviewees stated that before being beneficiaries of the program they were engaged in multiple activities, including open corn production (80.00\%), egg production and poultry breeding (53.30\%), cattle, goat and pig breeding (6.70\%), and open vegetable production (3.30\%).

The predominant type of land ownership was mostly private (53.57\%) and "ejido" (14.29\%). The rest of the beneficiaries stated that they did not have a property for staple crops planting but rented $(21.43 \%)$ or borrowed it (10.71\%). Of the total area owned by the assessed families, $86.36 \%$ corresponded to rainfed agriculture and $13.64 \%$ to irrigated agriculture.

It was found that among the families in the surveyed communities, it is common to carry out productive activities in their backyards, although without appropriate infrastructure. The average surface area of the backyards per family was $48.27 \mathrm{~m}^{2}$. The 
average surface area destined for the projects installed by the program was $25.3 \mathrm{~m}^{2}$ (52.00\%).

Before participating, the families already had birds in their backyards and experience in their management and care. For them, small species such as poultry, play an important role in the production of eggs and meat, foods that contribute to their diet. For this reason, most PESA beneficiaries chose poultry projects.

All PESA beneficiary families indicated that the program did contribute to improving their diets. However, the PESA projects did not achieve their objective, because only $16.12 \%$ were still operating, although with problems to maintain the flock, basically due to lack of inputs on their feed. Projects with low production represented 41.94\% and $41.94 \%$ of the projects were no longer operating.

The main reasons for which the projects where no longer operational were: lack of time to attend to the project (31.60\%); health problems of the families attending the birds (26.30\%); the project was not adapted to their needs (21.10\%); the beneficiaries were too old to attend to their project (10.40\%); the project was located in an inadequate site (5.30\%), and predators killed the flock (5.30\%).

The projects in operation had a deficient production due to the lack of resources to purchase inputs for diets (33.30\%), local inputs for the diets (30.60\%), locally available vaccines (22.20\%), resources for the purchase of the vaccines $(8.30 \%)$ and practical vaccines application training $(2.80 \%)$.

Fifty-one-point zero four percent of the interviewed families with projects still in operation mentioned that the project increased their monthly egg consumption by $16.20 \%$, although their production was not sufficient to meet their families' consumption needs. Therefore, all the interviewed people (100\%) mentioned that they bought eggs and chicken meat to supplement their consumption; in other words, the families were not able to produce enough food from their project to fully satisfy their consumption needs. This is consistent with what Verduzco et al. (2016) referred about that the poultry projects promoted by the PESA, in the state of Oaxaca were semi-intensive dual-purpose systems, with a 12 birds average flock size in reproductive age and poor productive and reproductive parameters, so they contributed scarcely to their food security or did not represent an income source for the beneficiaries.

In this same sense, in evaluations carried out by the United Nations Food and Agriculture Organization (FAO), the Ministry of Agriculture, Livestock, Fisheries and Food (SAGARPA) and the Economic Commission for Latin America and the Caribbean (CEPAL) reported that the PESA program contributed with generated income equivalent to $4.60 \%$ of the value of the daily per capita consumption of basic food basket products in rural communities (Mohar-Ponce, 2011). The Economic Commission for Latin America and the Caribbean also reported that the contribution was 1.20\% (Sema-Hidalgo et al., 2011). Similarly, the Centre for Scientific Studies (CECS-UACh, 2013) reported that the indicator eggs/hens/week did not represent an increase throughout the program's operation, but rather a declining production. 
The above contrasts with the study conducted by Montes de Oca et al. (2017), which reported that in the backyard poultry projects of the PESA program in the state of Morelos, $47.20 \%$ of the beneficiaries did obtain income, although it was of little or no contribution in the area for housing improvement, food, clothing, transportation, medical expenses, savings, entertainment and the creation of contingency funds, since they only made small-scale sales of surplus with their neighbours in the same locality, selling it mostly by piece. This was also the case in the present research.

Similarly, Trujano-Ramos (2017), in a research conducted in the state of Hidalgo, noted that PESA beneficiaries increased their production level, moving from selfconsumption to placing their products in local markets, taking advantage of their local resources, without representing a significant income for the families.

According to the goals set by the Rural Development Agency for the area of this study, backyard projects had to reach a production of $144 \mathrm{~kg}$ of eggs during a project cycle for newly installed projects and $169 \mathrm{~kg}$ per cycle in projects that were already operating.

In the present study, an average annual production of $187.2 \mathrm{~kg}$ was recorded in projects that were in operation, which indicates that the established goal was exceeded. However, according to the consumption needs of the families, this goal was not sufficient because the program beneficiaries were still buying eggs for family food; in other words, the PESA program helped little, so it is necessary to rethink their goals, in order to meet the food needs of the participating families. According to the obtained data, the main destination of their production was self-consumption with $72.73 \%$

\section{CONCLUSIONS}

The beneficiaries of the poultry projects supported by the PESA program improved their family diet with the consumption of eggs and meat and had greater availability of food for the basic food basket, although it was not enough for families to meet their consumption needs. In the projects that are still working, the families had difficulties in their operation. There was a downward trend in production due to inadequate management of the projects, due to the lack of inputs to support them, such as feed, vaccines, and replacements for the flocks.

\section{REFERENCES}

Centro de Estudios Científicos (CECS)-Universidad Autónoma de Chihuahua (UACh). (2013). Elementos de juicio para tomar decisiones sobre pre-dictamen de desempeño de ADR-PESA-Oax. Presentado en CECS, Oaxaca. Recuperado de:https:// www.redalyc.org/jatsRepo/153/15351156009/html/index.html.

Consejo Nacional de Evaluación de la Política de Desarrollo Social (CONEVAL). (2015). Medición de la pobreza en México. Recuperado el 8 de agosto del 2020 de https://www.coneval.org.mx/Medicion/Paginas/AE_pobreza_municipal.aspx.

INEGI (Instituto Nacional de Estadística, Geografía e informática). (2015). Encuesta intercensal. México. Recuperado de https:// www.inegi.org.mx/programas/intercensal/2015/. 
INEGI (Instituto Nacional de Estadística, Geografía e informática). 2010. Censo de población y vivienda. Municipio de Tepecoacuilco, Guerrero. Recuperado el 7 de noviembre del 2020 de https:/www.inegi.org.mx/contenidos/programas/ccpv/2010/tabulados/Basico/01_01B_MUNICIPAL_12.pdf.

Mohar Ponce, A. (2011). Estudio de Logros, Lecciones y Potencialidades del PESA Parte I. Pertinencia del PESA como una Estrategia de Seguridad Alimentaria e Inclusión Productiva en Zonas Marginales. Informe de resultados. México, D.F.: Organización de las Naciones Unidas para la Alimentación y la Agricultura (FAO) \& Secretaría de Agricultura, Ganadería, Desarrollo Rural, Pesca y Alimentación (SAGARPA). Recuperado de: https://idegeo.centrogeo.org.mx/uploaded/documents/PERTINENCIA_ DEL_PESA.pdf

Montes de Oca E., García F., Sainz M., \& Juantorena-Ugas A., (2017). Traspatios y percepción del Programa PESA. Acta Agrícola y Pecuaria, 3 (3): pp.70-86 Recuperado de file://E:/Downloads/Dialnet-TraspatiosYPercepcionDelProgramaPESA-6265603\%20(1).pdf.

Olvera-Hernández, J. (2017). Importancia de especies vegetales en el traspatio de familias campesinas del noreste de Puebla, México. Agroproductividad, 10(7): 21-26.

Sema-Hidalgo, B., Ordaz-Díaz, J. L. Li Ng, J. J., Mora Rivera, J. J., Solano-Flores, E., Zaragoza, M. L., Zárate-Ramírez, J., Pérez Nava, Y., Hernández Medina, R. \& Flores-Sepúlveda, D. (2011). Evaluación del Proyecto Estratégico para la Seguridad Alimentaria Guerrero sin hambre (PESA-GSH). Evaluación de impacto. México, D.F.: Comisión Económica para América Latina y el Caribe (CEPAL), Gobierno del Estado de Guerrero, \& Secretaría de Agricultura, Ganadería, Desarrollo Rural, Pesca y Alimentación (SAGARPA).

Torres-Oregón. F., \& Rendón-Rojas. L., (2017). Proyecto Estratégico de Seguridad Alimentaria ante el recorte presupuestal del Proyecto de Egresos de la Federación 2017. Economía Actual.10, (1) , pp. 15-18.

Trujano-Ramos, S. Y., Garza Bueno Laura Elena, Valtierra Pacheco Esteban, Solis Sanchez Juan Bernardo (2018). Del autoconsumo a la inserción en el mercado local en el marco del Programa Estratégico de Seguridad Alimentaria (PESA) en los municipios de Tianguistengo y Xochicoatlán, Hidalgo. Estud. soc. Rev. aliment. contemp. desarro. reg. 28 (52), pp. 2-23.

Vargas-López, S., Bustamante-González, A., Vargas-Monter, J., Hernández-Zepeda, J., Vázquez-Martínez, I., \& Calderón-Sánchez, F. (2018). Diversidad y prácticas de crianza de animales domésticos en traspatios de comunidades indígenas en Guerrero, México. Revista Agroproductividad, 10(7): 15-20.

Verduzco, C., Martínez, E., Muñoz, M., Santoyo, V., \& Aguilar, J. (2016). Estrategia de gestión de la innovación para la avicultura de traspatio en zonas rurales marginadas de Oaxaca, México. TRANSIATARE Revista de turismo, economía y negocios, 2 (2): pp165-182.

Zepeda, J., Vázquez-Martínez, I., \& Calderón-Sánchez, F. (2018). Diversidad y prácticas de crianza de animales domésticos en traspatios de comunidades indígenas en Guerrero, México. Revista Agroproductividad, 10(7): 15-20. 